\title{
KORELASI ANTARA SIKAP TOLERANSI DENGAN INTERAKSI SOSIAL DI KELAS SISWA KELAS IV SD GUGUS VII KUTA SELATAN TAHUN PELAJARAN 2017/2018
}

\author{
Ni Kadek Desrinita Manika Sari ${ }^{1}$, I Wayan Sujana ${ }^{2}$, I. B. Surya Manuaba ${ }^{3}$ \\ 1,2,3 Jurusan PGSD \\ Universitas Pendidikan Ganesha \\ Singaraja, Indonesia \\ e-mail: nitamanika9645@gmail.com ${ }^{1}$,iwayan.sujana@undiksha.ac.id ${ }^{2}$, \\ idabagussurya.manuaba@undiksha.ac.id ${ }^{3}$
}

\begin{abstract}
Abstrak
Penelitian ini bertujuan untuk mengetahui korelasi antara sikap toleransi dengan interaksi sosial di kelas siswa kelas IV SD Gugus VII Kuta Selatan. Jenis penelitian ini adalah penelitian ex post facto. Populasi dari penelitian ini adalah seluruh siswa kelas IV SD yang berada di Gugus VII Kuta Tahun Pelajaran 2017/2018 yang memiliki populasi sebanyak 123 siswa. Penentuan sampel menggunakan teknik proporsional random sampling dengan taraf kesalahan $5 \%$ dan diperoleh jumlah sampel dari populasi adalah 89 siswa. Data sikap toleransi dan interaksi sosial diperoleh melalui kuesioner yang dijawab oleh responden. Sebagai uji prasyarat adalah uji normalitas sebaran data. Setelah seluruh uji prasyarat terpenuhi, analisis statistik yang digunakan pada penelitian ini adalah uji hipotesis menggunakan analisis korelasi product moment. Berdasarkan hasil analisis maka $r_{\text {hitung }}=1,205$. Pada taraf signifikansi $5 \%$ dengan $\mathrm{n}=89$, maka diperoleh $r_{\text {tabel }}=0,213$. Karena $r_{\text {hitung }}=1,205>r_{\text {tabel }}=0,213$ maka dapat diartikan bahwa $\mathrm{H}_{0}$ yang berbunyi tidak terdapat korelasi yang signifikan antara sikap toleransi dengan interaksi sosial di kelas siswa kelas IV SD Gugus VII Kuta Selatan Tahun Pelajaran 2017/2018 ditolak dan $\mathrm{H}_{\mathrm{a}}$ diterima. Jadi dapat disimpulkan bahwa terdapat korelasi antara sikap toleransi dengan interaksi sosial di kelas siswa kelas IV SD Gugus VII Kuta Selatan, dengan arah korelasi positif, artinya semakin tinggi sikap toleransi maka semakin meningkatkan interaksi sosial di kelas.
\end{abstract}

Kata kunci: sikap toleransi, interaksi sosial di kelas

\begin{abstract}
The purpose of this research was to find out the correlation between tolerance attitudes with social interaction in Elementary School Gugus VII Kuta Selatan Grade 4. The type of this research was ex post facto. Research populationswere all students Grade 4 in Elementary School Gugus VII Kuta Selatan academic period 2017/2018 which has population over 123 students. Sample was determined by proportional technique random sampling with the level of error $5 \%$ and the number of sample gained from the populations were 89 students. The data from tolerance attitudes and social interactions were obtained through questionnaire which was answered by the respondents. The prerequisite test was data distribution normality test. After all the prerequisite test fulfilled, statistics analysis that was used in this research is hypothesis test using correlation analysis product moment. Based on the analysis result we found that $r_{\text {count }}=1,205$. At a level of signification $5 \%$ with $\mathrm{n}=89$, obtained $r_{\text {table }}=0,213$. Because $r_{\text {count }}=1,205>r_{\text {table }}=0,213$ it means that $H_{0}$ that said there is no significant correlation between tolerance attitudes with social interactions in Elementary School Gugus VII Kuta Selatan Grade 4 academic period 2017/2018 was rejected and $\mathrm{H}_{\mathrm{a}}$ was accepted. The conclusion was there is correlation between tolerance attitudes with social interactions in in Elementary School Gugus VII Kuta Selatan Grade 4, with positive correlation line, which means the higher tolerance attitudes will increase the social interactions in the class.
\end{abstract}

Keywords: tolerance attitude, social interactions in the class. 


\section{PENDAHULUAN}

Pendidikan merupakan upaya untuk meningkatkan suatu kualitas diri dan sarana untuk mengembangkan potensi yang dimiliki oleh seseorang. Semakin terdidiknya seseorang maka semakin tinggi pula taraf hidup yang dimiliki. Tujuan Pendidikan Nasional (Pasal 3 UU No 20 Sisdiknas Tahun 2003) yaitu berkembangnya potensi peserta didik agar menjadi manusia yang beriman dan bertaqwa kepada Tuhan Yang Maha Esa, berakhlak mulia, sehat, berilmu, cakap, kreatif, mandiri dan menjadi warga Negara yang demokratis serta bertanggung jawab. Namun ada banyak tantangan yang dihadapi oleh pemerintah untuk mewujudkan pendidikan tersebut, baik tantangan dari dalam (internal) maupun tantangan dari luar (eksternal). Tantangan internal terkait dengan kondisi pendidikan dengan tuntutan pendidikan yang mengacu kepada 8 Standar Nasional Pendidikan yang meliputi standar pengelolan, standar biaya, standar sarana prasarana, standar pendidik dan kependidikan, standar isi, standar proses, standar penilaian, dan standar kompetensi lulusan. Sedangkan tantangan eksternal yang dihadapi dunia pendidikan antara lain berkaitan dengan tantangan masa depan, kompetensi yang diperlukan dimasa depan, persepsi masyarakat dan perkembangan pengetahuan.

Pemerintah terus menerus dengan berbagai cara untuk mewujudkan tujuan pendidikan yang telah dirumuskan dalam Sisdiknas tahun 2003. Salah satu usaha yang ditempuh oleh pemerintah yaitu dengan cara penyempurnaan Kurikulum Tingkat Satuan Pendidikan (KTSP) menjadi Kurikulum 2013 yang mulai diberlakukan pada tahun pelajaran 2013/2014. Dalam UU Nomor 20 tahun 2003 tentang Sistem Pendidikan Nasional menyebutkan bahwa "Kurikulum adalah seperangkat rencana dan pengaturan mengenai tujuan, isi dan bahan pelajaran serta cara yang digunakan sebagai pedoman penyelenggaraan kegiatan pembelajaran untuk mencapai tujuan pendidikan tertentu".

Dalam proses pembelajaran di sekolah dasar pemerataan penerapan kurikulum 2013 belum semua tingkatan kelas di sekolah dasar menggunakan kurikulum 2013, seperti beberapa sekolah yang terdapat di Kabupaten Badung. Kecamatan Kuta Selatan merupakan bagian dari Kabupaten Badung, dimana dalam kecamatan tersebut khususnya di sekolah dasarhanyalah kelas II SD dan kelas IV SD yang menggunakan Kurikulum 2013, sementara kelas yang lainnya masih menggunakan kurikulum KTSP. Tetapi proses belajar mengajar masih dapat dilakukan secara optimal. Belajar dengan sungguh-sungguh dan optimal sangat menunjang terciptanya sumber daya manusia (SDM) yang berkualitas.

Susanto (2012:4) menyatakan bahwa

Belajar adalah suatu aktivitas yang dilakukan seseorang dengan sengaja dalam keadaan sadar untuk memperoleh suatu konsep, pemahaman, atau pengetahuan baru sehingga memungkinkan seseorang terjadinya perubahan perilaku yang relative tetap baik dalam berpikir, merasa, maupun dalam bertindak.

Dalam proses belajar mengajar, selain belajar dengan sungguh-sungguh suasana harmonis sangat didambakan oleh semua pihak, baik antara guru dengan siswa maupun antara siswa dengan siswa. Salah satu upaya untuk menciptakan suasana belajar yang harmonis dan tepat tujuan yaitu dengan cara memahami setiap karakter yang dimiliki oleh masing-masing siswa karena seperti yang diketahui setiap individu memiliki karakter yang berbeda-beda. Pendidikan karakter memiliki makna lebih tinggi dari pendidikan moral, karena pendidikan karakter tidak hanya berkaitan dengan masalah benar-salah, tetapi bagaimana untuk menanamkan kebiasaan tentang hal-hal yang baik dalam kehidupan, sehingga peserta didik memiliki kesadaran dan pemahaman yang tinggi, serta kepedulian dan komitmen untuk menerapkan kebajikan dalam kehidupan sehari-hari. Mulyasa (2013:1) menyatakan bahwa "Pendidikan karakter merupakan upaya untuk membantu perkembangan jiwa anak-anak baik lahir maupun batin, dari sifat kodratinya menuju kearah peradaban manusiawi dan lebih baik". Pendidikan karakter merupakan proses yang berkelanjutan dan tak pernah berakhir, sehingga menghasilkan perbaikan kualitas yang berkesinambungan, yang ditujukan pada terwujudnya sosok manusia masa depan, dan 
berakar pada nilai-nilai budaya bangsa. Pendidikan karakter bertujuan untuk meningkatkan mutu proses dan hasil pendidikan yang mengarah pada pembentukan karakter dan akhlak mulia peserta didik secara utuh, terpadu, dan seimbang sesuai dengan standar kompetensi lulusan pada setiap satuan pendidikan. Melalui pendidikan karakter peserta didik diharapkan mampu secara mandiri meningkatkan dan menggunakan pengetahuannya, mengkaji dan menginternalisasikan serta mempersonalisasikan nilai-nilai karakter dan akhlak mulia sehingga dapat terwujud dalam kehidupan sehari-hari. Salah satu sikap yang harus ditanamkan melalui pendidikan karakter adalah sikap toleransi.

Sikap toleransi sesungguhnya berkembang karena adanya keberagaman dalam berbagai dimensi kehidupan, dan melalui sikap toleransi diharapkan dapat terwujud keserasian dan keharmonisan hidup, jauh dari konflik-konflik dan ketegangan-ketegangan sosial, lebih-lebih lagi pertentangan dan permusuhan antar sesama siswa sekolah yang menyebabkan maraknya perilaku menyimpang seperti bullying yang dilakukan oleh siswa. Suharyanto (2013) berpendapat bahwa "Toleransi ialah bermurah hati dalam pergaulan, sabar, tenggang rasa, bersikap membiarkan atau memberikan kebebasan kepada pendirian orang lain sekalipun bertentangan dengan pendirian sendiri". Upaya untuk mewujudkan keharmonisan dalam proses pembelajaran melalui sikap toleransi, interaksi sosial juga sangat diharapkan dalam setiap proses pembelajaran karena siswa tidak dapat hanya mengandalkan diri sendiri dan guru, melainkan siswa harus mampu menjalin interaksi sosial yang baik dengan teman sekelas guna mendapatkan pengetahuan baru dan hasil belajar yang optimal, tetapi terkadang banyak siswa yang kurang memiliki motivasi untuk beradaptasi di lingkungan kelas maupun sekolah sehingga menyebabkan sulit terjadi interaksi sosial. Interaksi sosial terjadi jika dua orang atau lebih saling bertemu, kemudian saling tegur sapa, berjabat tangan dan saling berbicara. Dari peristiwa tersebut terdapat dua pihak dimana salah satu pihak memberikan aksinya, kemudian pihak lainnya memberikan respons (reaksi) terhadap aksi tersebut, maka dari sinilah kegiatan antara aksi dan reaksi dimulai. Kegiatan manusia di mana salah satu pihak memberikan aksinya dan pihak lain meresponsnya atau memberikan reaksi, maka kegiatan itu disebut interaksi. Interaksi sendiri sebenarnya berasal dari kata "antar" dan "aksi" yaitu aksi dan reaksi. Menurut Setiadi, dkk (2010:63) menyatakan bahwa "Interaksi sosial merupakan hubungan-hubungan sosial yang dinamis yang menyangkut hubungan antara orang-orang perorangan, antara kelompokkelompok manusia, maupun antara orang perorangan dan kelompok manusia". Interaksi sosial merupakan kegiatan antara manusia dengan manusia, bukan manusia dengan benda mati, binatang atau tumbuhan. Dengan demikian, selama aksi dan reaksi tidak terjadi antara manusia dan manusia, maka aktivitas tersebut bukan interaksi sosial. Sejalan dengan aktivitas individu tesebut penanaman sikap toleransi sangat diperlukan dan diharapkan mampu memengaruhi proses interaksi sosial siswa di kelas. Penelitian ini dilakukan untuk mengetahui apakah sikap toleransi memiliki korelasi yang signifikan dengan interaksi sosial di kelas, maka akan dilakukan penelitian berjudul "Korelasi Antara Sikap Toleransi Dengan Interaksi Sosial Di Kelas Siswa Kelas IV SD Gugus VII Kuta Selatan Tahun Pelajaran 2017/2018“.

\section{Metode}

Penelitian ini merupakan penelitian Ex Post Facto Korelasional karena penelitan ini bertujuan untuk mengetaui korelasi antara sikap toleransi dengan interaksi sosial di kelas, dengan tidak memanipulasi variabel bebas atau menggali fakta yag sudah terjadi sebelumnya. Populasi dalam penelitian ini adalah siswa kelas IV SD Gugus VII Kuta Selatan tahun pelajaran 2017/2018 yang berjumlah 123 siswa.

Berdasarkan tabel Issac and Michael, jumlah populasi yan terdapat di Gugus VII Kuta Selatan adalah 123 siswa dan jumlah sampel yang diambil berdasarkan tingkat kesalahan 5\% berjumlah 89 orang siswa. Pengambilan sampel dalam penelitian ini menggunakan teknik proporsional random sampling yang artinya teknik pengambilan sampel secara acak dengan memperhatikan jumlah siswa dari masing-masing kelas sesuai dengan proporsi yang terdapat didalam populasi tersebut. 
Metode yang digunakan dalam pengumpulan data adalah metode teknik non tes, jenis teknik non tes yang digunakan dalam penelitian ini yaitu kuesioner dan pencatatan dokumen. Dalam penelitian ini sesuai dengan data yang dikumpulkan, instrumen yang digunakan adalah kuesioner sikap toleransi dan interaksi sosial. Sedangkan pencatatan dokumen hanya untuk mencari absensi siswa kelas IV SD Gugus VII Kuta Selatan tahun pelajaran 2017/2018.

Kuesioner sikap toleransi dan interaksi sosial dibuat sendiri berdasarkan pembahasan di kajian teori yang digunakan sebagai pedoman indikator. Indikator sikap toleransi terdiri dari bersahabat/komunikatif, toleransi, menghargai prestasi, peduli sosial dan cinta damai. Sedangkan indikator interaksi sosial terdiri dari tanggung jawab, demokratis dan kerja keras. Kedua kuesioner tersebut sebagai alat ukur untuk mengetaui sejauh mana sikap toleransi dan interaksi sosial yang dimiliki oleh siswa kelas IV SD Gugus VII Kuta Selatan. Jumlah masing-masing item kuesioner yaitu 20 butir pernyataan. Pengujian instrumen dalam penelitian ini menggunakan validitas isi dan validitas konstrak. Cara pemberian skor pada kuesioner sikap toleransi dan kuesioner interaksi sosial yaitu menggunakan skala likert.

Pencatatan dokumen yang digunakan untuk pengumpulan data absensi siswa kelas IV SD Gugus VII Kuta Selatan Tahun Pelajaran 2017/2018. Analisis dalam penelitian ini menggunakan analisis statistik inferensial. Teknik analisis data yang digunakan teknik korelasi product moment yang digunakan unuk mencari hubungan dua variabel yaitu variabel bebas dan variabel terikat dengan menggunakan data interval atau ratio. Untuk memenuhi persyaratan uji hipotesis maka diperlukan uji persyaratan analisis yaitu uji normalitas dan uji hipotesis statistik.

Uji normalitas digunakan untuk menguji apakah data variabel bebas dan variabel terikat berdistribusi normal atau tidak, dengan cara menggunakan rumus chi-kuadrat dengan kriteria yang digunakan adalah dengan membandingkan nilai $X^{2}$ tabel dengan $X^{2}$ hitung pada taraf signifikan 5\% dengan ketentuan $\mathrm{X}^{2}{ }_{\text {hitung }}<\mathrm{X}_{\text {tabel }}$ maka data berdistribusi normal.

Uji hipotesis statistik menggunakan korelasi product moment dengan mengetes antara variabel bebas $(\mathrm{X})$ dan variabel terikat $(\mathrm{Y})$. Hipotesis yang diuji dalam penelitian ini adalah $\mathrm{H}_{\circ}$ yang berbunyi tidak terdapat korelasi yang signifikan antara sikap toleransi dengan interaksi sosial di kelas siswa kelas IV SD Gugus VII Kuta Selatan tahun pelajaran 2017/2018. Kriteria yang digunakan dalam pengujian korelasi product moment ini yaitu dengan menggunakan taraf signifikan $5 \%$. Adapun ketentuan yang diuji dalam penelitian ini

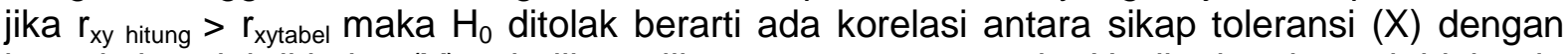
interaksi sosial di kelas $(Y)$ sebaliknya jika $r_{x y}$ hitung $<r_{x y}$ tabel maka $H_{0}$ diterima berarti tidak ada korelasi sikap toleransi $(\mathrm{X})$ dengan interaksi sosial di kelas $(\mathrm{Y})$.

\section{Hasil dan Pembahasan}

\section{Deskripsi Data Sikap Toleransi}

Data mengenai sikap toleransi siswa kelas IV SD Gugus VII Kuta Selatan diperoleh melalui penyebaran kuesioner. Sampel yang dibagikan kuesioner berjumlah 89 responden dengan 20 butir pernyataan. Data nilai kuesioner sikap toleransi dapat dilihat sebagai beirkut:

Tabel 1. Data Nilai Kuesioner Sikap Toleransi Siswa Kelas IV SD Gugus VII Kuta Selatan Tahun pelajaran 2017/2018

\begin{tabular}{|c|c|}
\hline Data Statistik & Nilai \\
\hline Mean & 82,584 \\
\hline Median & 83 \\
\hline Modus & 94 \\
\hline Skor Minimum & 63 \\
\hline Skor Maksimum & 94 \\
\hline
\end{tabular}


Berdasarkan data nilai kuesioner sikap toleransi siswa kelas IV SD Gugus VII Kuta Selatan Tahun Pelajaran 2017/2018 mendapatkan nilai 82,584. Nilai sikap toleransi siswa yang tertinggi 94 dan yang terendah 63 .

Dari data di atas dapat juga dilihat dalam bentuk grafik, sehingga dapat dilihat sebagai berikut :

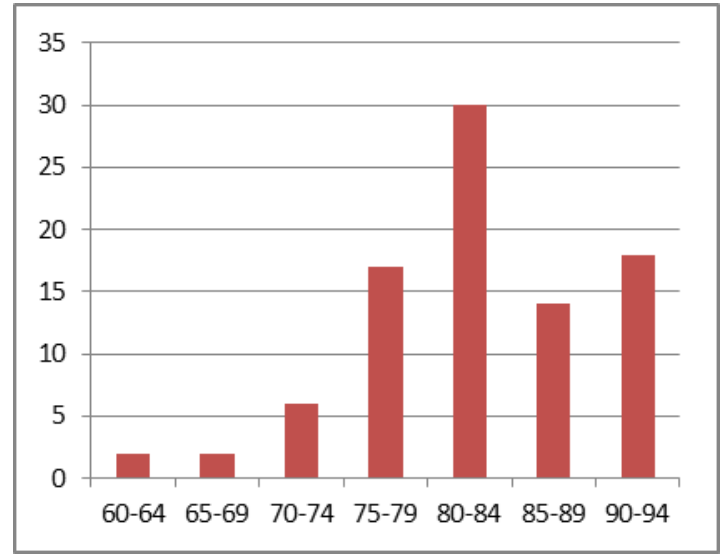

Gambar 1. Histogram Data Sikap Toleransi

Berdasarkan diagram tentang data sikap toleransi dapat diketahui bahwa frekuensi nilai terbanyak terdapat pada kelas interval ke-5, selanjutnya dapat dilihat tingkat kategori sikap toleransi siswa kelas IV SD Gugus VII Kuta Selatan Tahun Pelajaran 2017/2018 sebagai berikut:

Tabel 2. Pedoman Konversi PAP Skala Lima Sikap Toleransi

\begin{tabular}{cc}
\hline Persentase Sikap Toleransi & Kriteria Sikap Toleransi \\
\hline $90-100$ & Sangat Tinggi \\
$80-89$ & Tinggi \\
$65-79$ & Sedang \\
$55-64$ & Rendah \\
$0-54$ & Sangat Rendah \\
\hline & (Sumber:Agung,2014)
\end{tabular}

Berdasarkan kategori sikap toleransi diatas serta hasil analisis data, bahwa rerata dari sikap toleransi siswa kelas IV Gugus VII Kuta Selatan adalah 82,584. Berdasarkan data tersebut maka dapat disimpulkan bahwa nilai sikap toleransi siswa kelas IV SD Gugus VII Kuta Selatan, tergolong kategori tinggi.

\section{Deskripsi Data Interaksi Sosial di Kelas}

Data tentang interaksi sosial di kelas siswa kelas IV SD Gugus VII Kuta Selatan diperoleh melalui penyebaran kuesioner. Sampel yang dibagikan kuesioner berjumlah 89 responden dengan 20 butir pernyataan. Data nilai kuesioner interaksi sosial di kelas dapat dilihat sebagai berikut: 
Tabel 3. Data Hasil Nilai Kuesioner Interaksi Sosial di Kelas Siswa Kelas IV SD Gugus VII Kuta Selatan

\begin{tabular}{cc}
\hline Data Statistik & Nilai \\
\hline Mean & 80 \\
Median & 80 \\
Modus & 74 \\
Skor Minimum & 66 \\
Skor Maksimum & 99 \\
\hline
\end{tabular}

Berdasarkan data nilai interaksi sosial di kelas rata-rata siswa kelas IV SD Gugus VII Kuta Selatan Tahun Pelajaran 2017/2018 mendapatkan nilai 80. Nilai interaksi sosial di kelas tertinggi 99 dan yang terendah 66. Dari data di atas dapat juga dilihat dalam bentuk grafik, sehingga dapat dilihat sebagai berikut :

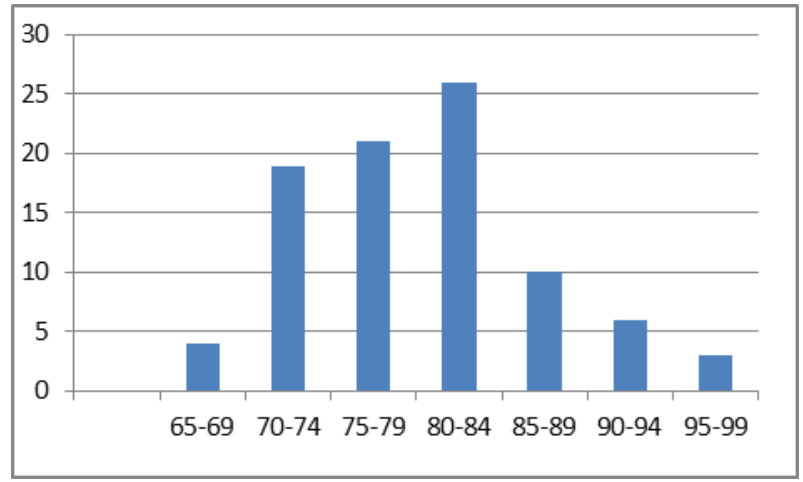

Gambar 2. Histogram Data Interaksi Sosial di Kelas

Berdasarkan diagram tentang data interaksi sosial di kelas dapat diketahui bahwa frekuensi nilai terbanyak terdapat pada kelas interval ke-4, selanjutnya dapat dilihat data berikut ini tentang tingkat kategori interaksi sosial di kelas siswa kelas IV SD Gugus VII Kuta Selatan Tahun Pelajaran 2017/2018.

Tabel 4. Pedoman Konversi PAP Skala Lima Interaksi Sosial di Kelas

Persentase Interaksi Sosial di Kelas

\begin{tabular}{cc}
\hline $90-100$ & Sangat Tinggi \\
$80-89$ & Tinggi \\
$65-79$ & Sedang \\
$55-64$ & Rendah \\
$0-54$ & Sangat Rendah \\
\hline Berdasarkan kategori interaksi sosial di atas serta hasil dari analisis data, bahwa
\end{tabular}

Berdasarkan kategori interaksi sosial di atas serta hasil dari analisis data, bahwa rerata dari interaksi sosial di kelas siswa kelas IV Gugus VII Kuta Selatan adalah 80. Berdasarkan data tersebut maka dapat disimpulkan bahwa nilai interaksi sosial di kelas siswa kelas IV SD Gugus VII Kuta Selatan, tergolong kategori tinggi. 


\section{Uji Prasyarat Analisis}

Uji normalitas sikap toleransi $(X)$ dan interaksi sosial di kelas $(Y)$ menggunakan teknik uji Chi-Kuadrat $\left(\mathrm{x}^{2}\right)$. Nilai dari variabel $\mathrm{X}$ dan $\mathrm{Y}$ dapat dikatakan berdistribusi normal apabila $x_{\text {hitung }}^{2}<x^{2}$ tabel.

Hasil uji normalitas sikap toleransi $(X)$ yaitu $x^{2}$ hitung $=5,9$. Berdasarkan analisis maka diperoleh $\mathrm{x}^{2}$ hitung $=5,9$ dan menggunakan taraf signifikansi $5 \%$ dengan menggunakan derajat kebebasan 5, maka diperoleh $x^{2}$ tabel $=11,07$. Hal ini berati $x^{2}$ hitung $5,9<x^{2}{ }_{\text {tabel }} 11,07$ maka dapat dinyatakan sebaran data berdistribusi normal. Sedangkan hasil uji normalitas interaksi sosial di kelas $(Y)$ yaitu $x^{2}{ }_{\text {hitung }}=3,27$. Berdasarkan analisis maka diperoleh $x^{2}{ }_{\text {hitung }}=3,27$ dan menggunakan taraf signifikansi $5 \%$ dengan menggunakan derajat kebebasan 5 , maka diperoleh $x^{2}$ tabel $=11,07$. Hal ini berati $x^{2}$ nitung $3,27<x_{\text {tabel }}^{2} 11,07$ maka dapat dinyatakan sebaran data berdistribusi normal. Hasil tersebut membuktikan bahwa data kedua variabel bebas dan terikat bersifat normal.

\section{Pengujian Hipotesis}

Setelah dilakukan uji prasyarat dan diketahui data berdistribusi normal, dilanjutkan uji hipotesis guna mengetahui adanya korelasi antar variabel. Uji hipotesis yang dilakukan adalah uji hipotesis dengan menggunakan teknik analisis product moment (variabel $\mathrm{X}$ dengan variabel $\mathrm{Y}$ ), maka untuk tujuan analisis data dirumuskan dalam hipotesis nol $\left(\mathrm{H}_{0}\right)$. Hipotesis yang dirumuskan yaitu $\mathrm{H}_{0}$ : Tidak terdapat korelasi yang signifkan antara sikap toleransi dengan interaksi sosial di kelas siswa kelas IV SD Gugus VII Kuta Selatan Tahun Pelajaran 2017/2018.

Berdasarkan tabel penolong untuk mencari nilai $r$ dengan menggunakan rumus product moment dan dibantu menggunakan Microsoft excel 2007. Pengujian koefisien korelasi dengan rumus product moment diperoleh hasil $r_{x y}=1,205$. Untuk uji koefisien korelasi, digunakan nilai tabel product moment $(r)$ untuk $n=89$, pada taraf signifikansi $5 \%$ diperoleh angka sebesar 0,213. Maka dapat dinyatakan $r_{\text {hitung }}>r_{\text {tabel }}$. Ini berati nilai $r_{\text {hitung }}$ signifikan dengan nilai 1,205 , sehingga $\mathrm{H}_{0}$ yang berbunyi tidak terdapat korelasi yang signifikan antara sikap toleransi dengan interaksi sosial di kelas siswa kelas IV SD Gugus VII Kuta Selatan Tahun Pelajaran 2017/2018 ditolak, dan $\mathrm{H}_{\mathrm{a}}$ diterima. Berdasarkan hasil perhitungan $r_{\text {hitung }}$ dengan membandingkan $r_{\text {tabel }}$ dilihat dari hasilnya hal ini menunjukan bahwa terjadi korelasi, antara sikap toleransi dengan interaksi sosial di kelas. Sedangkan arah korelasi, dari hasil penelitian ini yaitu arah korelasi positif berarti semakin tinggi sikap tolerans yang dimiliki siswa maka semakin meningkat interaksi sosial di kelas.

\section{PEMBAHASAN}

Berdasarkan uraian di atas maka dalam penelitian ini diperoleh $r_{\text {hitung }}=1,205$ dan $r_{\text {tabel }} 0,213$ yang berarti $r_{\text {hitung }}>r_{\text {tabel }}$, dan hasil analisis yang diperoleh $r_{\text {hitung }}>r_{\text {tabel, }}$, sehingga $\mathrm{H}_{0}$ yang berbunyi tidak terdapat korelasi yang signifikan antara sikap toleransi dengan interaksi sosial di kelas siswa kelas IV SD Gugus VII Kuta Selatan Tahun Pelajaran 2017/2018 ditolak dan $\mathrm{H}_{\mathrm{a}}$ diterima. Berdasarkan uraian yang telah dipaparkan dapat dikemukakan interprestasi, yang membuktikan rata-rata siswa kelas IV SD di Gugus VII Kuta Selatan tergolong memiliki sikap toleransi tinggi dan memiliki sikap interaksi sosial di kelas tinggi.

Berdasarkan hal tersebut tingginya sikap toleransi yang dimiliki oleh siswa didukung oleh beberapa faktor. Seperti faktor internal yang berasal dari dalam diri siswa itu sendiri yang memiliki sifat mampu untuk menerima segala perbedaan dan keberagaman yang ada di lingkungan sekolah maupun kelasnya. Hal ini sependapat dengan apa yang dikemukakan oleh Endang (2009:Vol.1) yang mengatakan bahwa "Sikap toleransi yang di dalamnya mengandung nilai-nilai penghargaan, rasa hormat terhadap hak-hak perbedaan serta keberagaman orang lain merupakan bagian dari pendidikan umum". Hal tersebut tentu ada kaitannya dan sangat berpengaruh terhadap interaksi sosial siswa. Tingginya sikap toleransi akan berpengaruh terhadap perkembangan siswa dalam bergaul, khususnya dalam berinteraksi. Interaksi sosial adalah hubungan timbal balik yang saling memengaruhi satu 
sama lain, ada aksi dan ada reaksi dan pelakunya lebih dari satu orang. Menurut Sudjarwo $(2015: 87)$ "Interaksi sosial yang dikembangkan pada peserta didik pada situasi apapun, besar atau kecil bibit interaksi tersebut akan tetap bermuatan nilai-nilai pendidikan".

Tingginya sikap toleransi dan interaksi sosial dalam penelitian ini juga dipengaruhi oleh faktor eksternal yang dimiliki oleh siswa. Seperti yang dikemukakan oleh Kemendikas (dalam Kurniasih dan Sani, 2017:138) ada 18 nilai yang dikembangkan dalam pendidikan budaya dan karakter bangsa yang diharapkan dimiliki oleh setiap individu. 18 nilai yang dikembangkan adalah nilai religius, jujur, toleransi, disiplin, kerja keras, kreatif, mandiri, demokratis, rasa ingin tahu, semangat kebangsaan, cinta tanah air, menghargai prestasi, bersahabat/komunikatif, cinta damai, gemar membaca, peduli lingkungan, peduli sosial dan tanggung jawab.

Berdasarkan hal tersebut, terlihat jelas sikap toleransi sangat memengaruhi interaksi sosial siswa melalui nilai-nilai karakter yang dimiliki oleh masing-masing siswa. Semakin tinggi sikap toleransi, maka semakin tinggi pula interaksi sosial yang dimikili oleh siswa. Dalam penelitian ini untuk uji koefisien korelasi, digunakan nilai tabel product moment $(r)$ untuk $n=89$, pada taraf signifikansi $5 \%$ diperoleh hasil adalah 0,213 . Maka dapat dinyatakan $r_{\text {hitung }}>r_{\text {tabel. }}$. Ini berati nilai $r_{\text {hitung }}$ signifikan dengan nilai 1,205 , sehingga $H_{0}$ yang berbunyi tidak terdapat korelasi yang signifikan antara sikap toleransi dengan interaksi sosial siswa kelas IV SD Gugus VII Kuta Selatan Tahun Pelajaran 2017/2018 ditolak dan $\mathrm{H}_{\mathrm{a}}$ diterima.

\section{Simpulan dan Saran}

Hasil analisis menunjukan bahwa terdapat korelasi yang signifikan antara sikap toleransi dengan interaksi sosial di kelas siswa kelas IV SD Gugus VII Kuta Selatan Tahun Pelajaran 2017/2018. Arah korelasi adalah positif karena nilai r positif, yang artinya semakin tinggi sikap toleransi semakin meningkatnya interaksi sosial di kelas.

Berdasarkan hasil analisis dengan menggunakan Microsoft excel 2007 dan menghitung manual diperoleh $r_{\text {hitung= }} 1,205$ dengan $r_{\text {tabel }}$ 0,213 yang berarti $r_{\text {hitung }}>r_{\text {tabel }}$, sehingga $\mathrm{H}_{0}$ yang berbunyi tidak terdapat korelasi yang signifikan antara sikap toleransi dengan interaksi sosial di kelas siswa kelas IV SD Gugus VII Kuta Selatan Tahun Pelajaran 2017/2018 ditolak.

Berdasarkan uraian tersebut dapat dikemukakan interprestasi, bahwa rata-rata siswa yang tergolong memiliki sikap toleransi yang tinggi dan siswa dapat memperoleh nilai interaksi sosial di kelas yang tinggi pula. Jadi dapat disimpulkan bahwa korelasi antara sikap toleransi dengan interaksi sosial di kelas memiliki korelasi dengan arah korelasi positif pada kategori korelasi sangat kuat.

Adapun saran yang ingin disampaikan sebagai berikut: (1) Kepada guru, berdasarkan temuan penelitian yang diperoleh, disarankan kepada guru agar lebih menumbuhkan dan membentuk sikap toleransi dan interaksi sosial pada siswa sejak dini agar membbantu siswa dalam proses belajar dikelas sehingga tujuan pembelajaran tercapai secara optimal. (2) Kepada sekolah, berdasarkan temuan penelitian, disarankan kepada kepala sekolah agar dapat menggunakan hasil penelitian ini sebagai pendukung sumber belajar guru dalam meningkatkan kualitas pembelajaran dengan membentuk dan menumbuhkan sikap toleransi dan interaksi sosial dalam belajar di sekolah sehingga sekolah mampu menghasilkan siswa yang berkualitas. (3) Kepada peneliti lain, berdasarkan temuan penelitian, disarankan kepada peneliti agar hasil penelitian ini digunakan sebagai referensi untuk melaksanakan penelitian selanjutnya dan semoga penelitian ini bermanfaat bagi seluruh masyarakat yang menggunakan penelitian ini.

\section{Daftar Rujukan}

Agung, Gede.2014. Metodelogi Penelitian Pendidikan. Malang: Aditya Media Publising. 
Agung Suharyanto.2013. Peranan Pendidikan Kewarganegaraan Dalam Membina Sikap Toleransi Antar Siswa.

Busri Endang. 2009. Mengembangkan Sikap Toleransi dan Kebersamaan di Kalangan Siswa. Volume 1, Nomor 2.

Kurniasih \& Berlin. 2017. Pendidikan Karakter. Jakarta: Kata Pena

Setiadi \& Husman. 2011. Pengantar Sosiologi. Jakarta: Kencana Prenamedia Group.

Sisdiknas. 2003. Tujuan Pendidikan Nasional

Sudjarwo.2015.Proses Sosial Dan Interaksi Sosial Dalam Pendidikan.Bandung:CV Mandar Maju.

Susanto, Ahmad. 2014. Teori Belajar dan Pembelajaran Di Sekolah Dasar. Edisi Pertama. Jakarta: Kencana Prenadamedia Group. 